\title{
WHITMAN'S COLUMBIA: \\ THE COMMEMORATION OF THE WORLD'S \\ COLUMBIAN EXPOSITION OF 1893 IN "A THOUGHT OF COLUMBUS"
}

\author{
ANDREW VOGEL
}

FROM THE MOMENT the intent to host the World's Columbian Exposition of 1893 was announced in 1890, the whole country was eagerly talking about it. ${ }^{1}$ The event was intended to reflect America's new-found prominence on the world stage by celebrating the four centuries of progress since Christopher Columbus discovered the Americas, and hardly any publication lacked some mention of the event. While the Exposition was being planned many readers of poems like "Passage to India," "Song of the Exposition," and "Prayer of Columbus" thought that Walt Whitman should have been involved in some direct way. For instance, Illustrated American thought he would make an ideal representative for the fair, publishing in 1891 an anonymous editorial criticizing the Exposition planners' request of a commemorative poem from Alfred Lord Tennyson. The editorial questions the choice of Tennyson and argues instead for an American, ideally Whitman:

But best of all would be an American poet. The children of the New World, which Columbus revealed to the Old, are best fitted to celebrate the glories of the new dispensation.

Walt Whitman would be the ideal choice. He is an American, a democrat in the largest and best sense of the word, a son of the soil. He could give us a splendid chant, full of virility and breadth and wisdom. But we have not yet reached the ideal stage where we can appreciate him at his true worth. ${ }^{2}$

Later the same year, George Horton of the Chicago Herald requested in a letter that Whitman write an exclusive poem for his paper to commemorate the Exposition. Horton indicates that he had approached several other prominent poets, but flatteringly adds that any list of contemporary poets would be incomplete without Whitman. Appealing to Whitman's penchant for self-promotion, Horton promises that "the West is anxious to hear from you on the subject, and The Herald reaches the West very widely" ( $W W W C, 8: 446)$. Similarly, a souvenir collection of 
thoughts on Columbus and America published in 1892 to commemorate the Exposition quotes Reverend Myron Reed, who insists, "we shall remember Walt Whitman, if only for the line, 'O America! We build for you because you build for the world." "3 Closer to home, Horace Traubel had tried numerous times to impel Whitman to write something for the fair. Traubel reports on November 11, 1891, that a San Francisco paper was "warmly advocating W. as poet for the Columbian Exposition" ( $W W W C, 9: 138)$. Yet Whitman complained time and again that he was unable to write any more poems. It did not matter to him how many requests he received ( $W W W C, 9: 126)$. Traubel records that on September 11,1891, Whitman said to him, "I have had fully half a dozen applications for poems lately - poems for public occasions - to none of which have I even replied" (WWWC, 8:499). Putting the matter firmly to rest, Whitman died seven months prior the Exposition's dedication ceremonies, and he was never formally recognized by the Exposition's planners and promoters. As a result, links between Whitman and the Columbian Exposition have gone unexamined. However, reading the last poem Whitman wrote, "A Thought of Columbus," within the context of the vast promotions that wed the Columbian discovery to American progress since 1492 suggests that Whitman's final poetic statement was dedicated to the spirit of the fair. Read in this light, "A Thought of Columbus" takes on a greater resonance.

Whitman's abiding interest in American progress was well understood as America took stock of itself in the twilight of the nineteenth century, and it is clearly on such grounds that Whitman's contemporaries drew a connection between him and the objectives of the Columbian Exposition. Indeed, the Exposition would have been the perfect vehicle for situating Whitman in the central place in American letters to which he had aspired throughout his career. America had assumed a greater prominence on the world stage by 1893 , thus validating Whitman's faith in the abundance of the land, the strength of democracy, and the growth of what he termed the "Western character" in "A Backward Glance O'er Travel'd Roads." "The genteel tradition that had marginalized Whitman throughout his career was losing its grip on American letters as an emerging generation warmly embraced Whitman's frankness and free verse style. But perhaps most signally, the Columbian Exposition organized itself around themes that had occupied Whitman's writing for decades, themes like the relationship between art and technology, American progress, the democracy of the republic, and, crucially, Columbus as a transformative figure in world history. ${ }^{5}$

Whitman's interest in the link between Columbus and social progress through technology dated back to the early 1870 s with the publication of "Passage to India" and "Song of the Exposition." In the former 
Whitman characterizes Columbus as "History's type of courage, action, faith," despite the fact of Columbus's changing fortunes, swinging from "great fame" to imprisonment and "dejection, poverty, death" $(L G, 417)$. Columbus's greatness, according to the poem, is measured not merely by the accidents of his life but by his ambition: "Ah Genoese thy dream! thy dream! ... The shore thou foundest verifies thy dream" $(L G, 414)$. The admiral's dream was merely a trade route to India, yet the poem argues that the course of the soul's evolution toward the transcendental unification of "Nature and Man" must follow the work of conquerors, explorers, traders, scientists, and engineers, and it will ultimately culminate in the development of the American continent as a sort of bridge through the construction of transportation and communication technology $(L G, 416)$. With increased communication, what the North American continent has become verifies Columbus's dream of a passage to India. The implied Columbian bridge connects the East to the West, the past to the future, and the material world to the transcendental soul.

"Song of the Exposition" likewise takes up the transcendental significance of technology in the New World and explicitly links it to the exhibition of national products. ${ }^{6}$ In this poem Whitman imagines a golden dome surmounted by the flag of the republic, and in this great edifice "all that forwards perfect human life [will] be started, / Tried, taught, advanced, [and] visibly exhibited" ( $L G, 200)$. Whitman attributes all the various displays of the exhibition to two combined things: first, "whatever forms the average ... and helps its present life to health and happiness," and second, the muse Columbia $(L G, 202)$. That is, the quotidian life and labor of regular Americans is an expression of the muse, Columbia, the same muse who inspired all the great civilizations. Transplanted to America, however, Columbia inspires greater technological developments and "different, prouder songs, with stronger themes" (LG, 201). "Song of the Exposition" illustrates how the New World, so called, verifies the old Genoese's dream of a bridge linking East and West: "This earth all spann'd with iron rails, with lines of steamships threading every sea" $(L G, 203)$. Columbia, so named for her founder and representative, is the spirit to connect and combine, and through combination progress attains. The exhibition halls of the Centennial celebration reflect that spirit and display the various material means by which the Columbian continent manifests such progress.

This theme of American promise and progress is also taken up in "Prayer of Columbus" (1874), which Whitman privately allowed contained more than a dash of autobiography. ${ }^{7}$ In dramatic monologue, the aged, abused Columbus is figured here as a baffled mystic. While on the one hand he suffers - scorned, chained, and debilitated-on the other he is taken by visions of "newer better worlds" and "anthems in new 
tongues" lauding him ( $L G, 423)$. These anthems will be sung, Columbus dreams, because the "earth's elder cloy'd and stifled lands uncloy'd, unloos'd, / By me the hemispheres rounded and tied, the unknown to the known" $(L G, 422)$. Columbus attributes his accomplishment to God:

O I am sure they really came from Thee,

The urge, the ardor, the unconquerable will,

The potent, felt, interior command, stronger than words,

A message from the Heavens whispering to me even in sleep,

These sped me on. $(L G, 422)$

Thus the discovery and all that is latent in it, which Columbus can only guess and thus Whitman leaves implied, are rooted in a divine providence that has yet to be fully revealed. In "Passage to India" Whitman pictures a great poet-implicitly a projection of himself - as picking up and acclaiming Columbus's ultimate but uncompleted project, which had been to chart the route to unified, global transcendence. In "Song of the Exposition" it seems that many of the elements are in place for the Columbian continent to fulfill the promise inherent in the discovery. Yet later in "Prayer of Columbus," Whitman identifies with a broken Columbus, so he leaves the culmination and celebration of both of their dreams and the divine plan to future celebrations.

Given Whitman's dovetailing investments in Columbus, American progress, and exhibitions of technologies, it would be surprising for him to make no remark regarding the Columbian Exposition while its planning was being regularly trumpeted in the national press. Expressly dedicated to celebrating the outcomes of Columbus's discovery, the World's Columbian Exposition was a defining event in American cultural history. As Robert Muccigrosso has argued, nothing "captured the public imagination in 1893 like the Chicago World's Fair." For instance, Hamlin Garland famously pleaded with his parents, "sell the cookstove if necessary and come. You must see the fair." ${ }^{8}$ Somewhat as Whitman envisioned in "Song of the Exposition," millions of Americans from all regions of the country converged to participate in the Columbian Exposition; "With all thy wide geographies," he wrote, "Behold America! ... As in procession coming" ( $L G, 203)$.

Indeed, Whitman would have relished the attractions of the Exposition. Those who heeded calls like Garland's and did make it to Chicago sent home the first picture postcards. They strode a moving sidewalk and rode in battery-powered horseless carriages. It was the first time many tried mass-produced consumer brands like Pabst Beer (the notorious blue ribbon was won there), Cracker Jack, Cream of Wheat, Shredded Wheat, Aunt Jemima Syrup, and Juicy Fruit chewing gum. The Pledge of Allegiance was written and the Columbus Day holiday established so that, 
in the words of President Harrison, citizens might "devote themselves to such exercises as may best express honor to the discoverer and their appreciation of the great achievements of the four completed centuries of American life."Visitors saw the moving pictures of Edison's Kinetoscope and heard music carried by cable from New York. In honor of the fair, Dvorak composed his New World Symphony, which was counterpointed by new compositions by John Philip Sousa on the one hand and Scott Joplin's ragtime on the other. The event inspired the first Baedeker's guide to the United States, lending a certain cosmopolitan legitimacy to American tourism. ${ }^{9}$ In addition, the buildings of the White City, as the grounds came to be known, symbolized a powerful mythology of American unity and exceptionalism. On display within the buildings were technological wonders that supposedly illustrated the inevitable results of American entrepreneurial capitalism. Meanwhile, the Midway Plaisance provided diverting entertainment for the millions of visitors. Crowned with the first Ferris Wheel, the Midway augured a new form of American entertainment-the amusement park. ${ }^{10}$ Such activities manifested Whitman's call to exhibit for public consumption "the rills of civilization" and songs praising "Practical, peaceful life, the people's life, the People themselves" ( $L G, 200,201)$.

Touching so many aspects of American life, the Columbian Exposition magnified many of the hopes and anxieties that were playing at the core of the nation's sense of itself, just as Whitman hinted that exhibitions should. The idea for a world's fair commemorating Columbus's voyage had been proposed as early as the 1880 s. St. Louis, Cincinnati, Chicago, New York, and Mexico City were initially among the proposed locations for such an event. As news of the success of the 1889 Paris World's Fair began to circulate, the quatercentenary idea solidified in the American imagination, and sectional rivalries sprang up over the best city to host. As the field was winnowed to two possibilities, an acerbic confrontation erupted between New York and Chicago. The antagonism between these cities rehearsed a pattern of East-West rivalry with deep historical roots readily palpable in the daily affairs of the country, most notably in the Populist movement. Congress settled the Exposition dispute with a legislative act on April 25, 1890. The unstated yet commonly understood purpose was to draw international attention to American contributions to world progress. For an emerging nation keen on demonstrating its burgeoning power on the world stage, hosting a world's fair carried significant implications and opportunities, and placing it in Chicago, America's great western city, lent an unmistakable symbolic resonance. ${ }^{11}$

However, the selection of Chicago fomented anxiety for some. Easterners in particular doubted whether Chicago could possibly match the Parisian Exposition, with its great symbol, the Eiffel Tower. People 
doubted whether Europeans would even entertain the idea of visiting a world's fair in a recently rebuilt western American city populated largely by immigrants. With ideas of history, nationalism, and progress tightly intertwined, Americans harbored a deep concern that America and Chicago, each with relatively short histories, remained inferior to European civilization and culture. According to Muccigrosso, "while many boasted loudly of American superiority, they remained sorely sensitive to reproofs from Europeans and, for that matter, from European-oriented Easterners" (65). Yet, despite the risks of failure and embarrassment, the Columbian Exposition was generally seen as an opportunity for the United States, as the perceived leader of the Americas, to demonstrate its proper place on the world stage, and it was seen as an opportunity for Chicago to demonstrate itself as a uniquely American, but also worldclass, city. ${ }^{12}$ The architectural planners devised a cohesive vision by which the all-white, neoclassical exhibit buildings intentionally suggested that America had claimed a place in the tradition of Western civilization. The White City also deliberately intimated a sense of national unity. In a country still wrestling with the legacies of slavery, the Civil War, and Reconstruction, this symbolic performance of unity carried no small importance. ${ }^{13}$ Yet it was the fact of the westering of American power that stood out. Louis Sullivan's Transportation Building deliberately referenced Whitman's "Passage to India," and the setting sun motif of his Golden Doorway subtly implied that the direction of progress in transportation technologies pointed west. ${ }^{14}$ Likewise, lending academic legitimacy to Whitman's beliefs about the West, Frederick Jackson Turner's "frontier thesis" argued that contact with the Western frontier defined the development of American culture and institutions, making them distinct from European models. ${ }^{15}$ Buffalo Bill Cody's Wild West show packaged such narratives of American power and colonial exceptionalism as thrilling diversion. ${ }^{16}$ The pervasive rhetoric of See America First boosterism evoked the American landscape as far more valuable, entertaining, and edifying than the capitals of European civilization. ${ }^{17}$ Thus, the selection of Chicago for the Exposition galvanized a narrative of American greatness grounded in the landscapes of the West which echoed Whitman's elevation of America's western character.

Discussions of Columbus's significance for the fair echo Whitman as well. Century Magazine pointedly limned the significance of the admiral for the event, stating, "it is the object of that exposition to celebrate, in a manner worthy of our position and power as a nation, the discovery of this country by Columbus four hundred years ago." 18 Following such logic, an abundance of material documenting and commemorating Columbus's life, the discovery of the Americas by Europeans, and the historical significance of America ever since circulated through the public 
sphere between 1890 and 1893 . Often, writers directly compared the flourishing of ideas in the Renaissance to their own historical moment. To mark the fourth centenary, the NerwYork Times published two profiles of Columbus's exploits to illustrate "the firm constancy of purpose and loftiness of spirit displayed by the grand old Genoese from the time he elaborated his idea of discovery." ${ }^{19}$ Likewise, in a speech delivered in Sacramento, California, President Harrison acclaimed the "pride that our people have achieved so much; that, triumphing over the hardships of the early pioneers, who struggled in the face of discouragement and difficulties more appalling than those that met Columbus when he turned the prows of his little vessels toward an unknown shore ... they have established civil institutions and set up the banner of the imperishable Union" (qtd. in CCMC, 359).

Similarly, Edward Augustus Freeman argued in Chautauqua magazine that "the discovery of the New World was something so startling as to help very powerfully the general enlargements of man's mind" (qtd. in CCMC, 135). In Christopher Columbus, an opera depicting Columbus's voyage, the Spanish King Ferdinand prophetically alludes to the significance of Columbus's voyage and implicitly the New World. He sings, "Where havoc reigned and strife her scorpions flourished, / Art, Industry, and Science shall be nourished; / And progress marshal us with wings unfurl'd, / to lead alike in war and peace the World." ${ }^{20}$ Making the neat comparison between the end of the fifteenth century and the end of the nineteenth explicit in Harper's Weekly, Amos Wright maintains that the discovery "marked the certain beginning of an enterprise which had a profound effect upon the welfare of the human race. Advancing civilization had been rapidly paving the way for it. There are ages of special mental activity in which mankind seems to progress much more swiftly than in others. The present is eminently an era of the kind." ${ }^{21}$ Such panegyrics echo the admiration for Columbus that Whitman cultivated directly in "Passage to India" and "Prayer of Columbus" and implicitly in "Song of the Exposition."

With fanfare that Whitman may have read about and certainly would have enjoyed, replicas of Columbus's caravels had been sailed to Chicago from Spain and were anchored alongside the Exposition's replica of La Rabida Monastery, the refuge where Columbus planned his voyage. La Rabida housed rare documents and relics of Columbus, the Castilian monarchy, and the ancient church. This along with representations of Columbus situated atop the Court of Honor's peristyle, placed at the entrance to the administration building, and adorning the official medals, the imagery of Columbus within the fair itself indicates the complex layering of values that the Exposition fostered. For instance, the cover of Campbell's Illustrated Fair Fournal frames an image of Columbus with the 


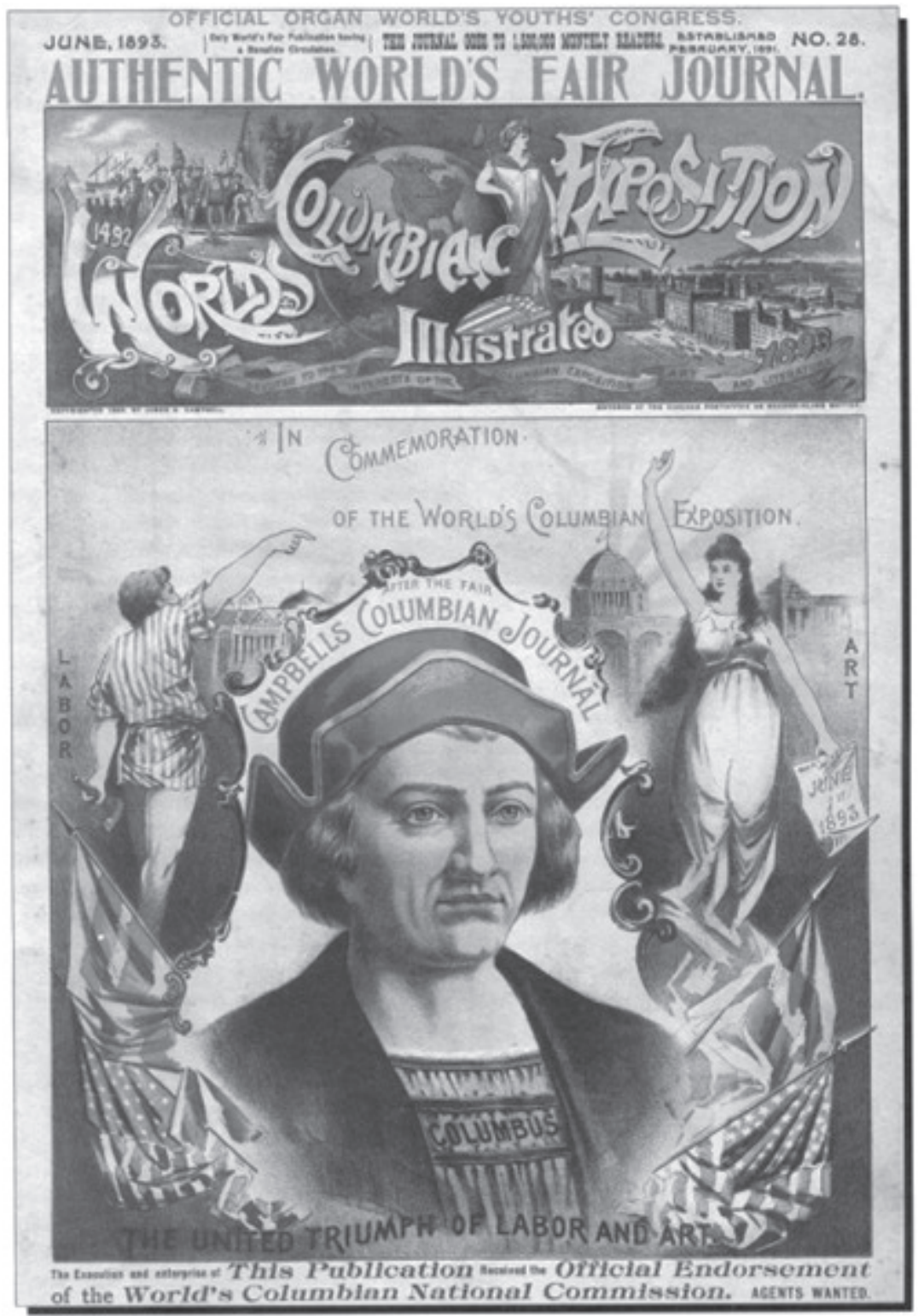

Figure 1. Cover of Campbell's Illustrated Fournal of the Columbian Exposition, June 1893, depicting Columbus as the embodiment of the link between art and labor represented by the Word's Fair and America's progress in the four centuries since the discovery. Reprinted in Norman Bolotin and Christine Laing, The Chicago World's Fair of 1893, The World's Columbian Exposition (Washington, D. C.: National Preservation Press, 1992), x. 
flags of Spain and the United States, figuring him as the representative American immigrant [Figure 1]. Fronting an image of the Exposition grounds and framed also by the allegorical figures of Art and Labor, Columbus embodies the merging of hard work and ambitious craft necessary to the national prosperity and progress that the fair promoted. The illustration's banner situates Columbus's 1492 landing in the upper left corner, opposite an 1893 image of Chicago, proudly depicting busy streets, high-rises, and smoking factories. In between, an allegorical figure fusing features of Liberty, the Republic, and Columbia leans on the earth, which is rotated to feature North America and Chicago. Altogether the elements of the illustration suggest that the seed of the republic - its prosperity, its innovation, its industry, and its culture-was planted on American soil with the 1492 discovery, a moment marking the first germination of modern progress. ${ }^{22}$ Crucially, such figurations echo the pattern of deploying Columbus to represent American progress and prosperity developed so forcefully by Whitman.

Not all contemporary portraits of Columbus were so laudatory, however, and given his strong identification with Columbus, Whitman would have been sensitive to this. For instance, the Atlantic Monthly argues in a review of two biographies of Columbus that everything admirable in his character is attributable to blind faith in his own delusions. According to this reviewer, Columbus was "a man who, from brooding over a great idea, identifies himself with it, and, so far from renouncing anything, grasps at whatever comes within reach of his purpose." "He was forever obeying his illusions," the reviewer sneers; "they were forever suffering disenchantment." Stripping Columbus of the visionary hero mantle, this critic concludes that the discovery of the Americas by Europeans "was the incarnation of an idea held in common with others, but carried to its practical consummation only by [Columbus] himself." 23 Charles Kendall Adams's 1892 biography pointedly criticizes Columbus for his greed and moral shortsightedness when it came to the practice of slavery. ${ }^{24}$ Likewise, Harry Hakes deflates the notion that Columbus discovered America, yet he casts Columbus as "a flexible and uncertain instrument in the unconscious embrace of blind fate, good fortune, or a bountiful Providence, blindly led to the grandest geographical discovery which has ever blessed mankind." Such biographies criticize Columbus personally, but none of them downplay the historical significance of the 1492 discovery. As Hakes put it, the discovery of the Americas "in its immediate and remote consequences and effects upon the happiness, well-being and expansion of mankind, fairly transcends every other event in the history of the world." ${ }^{25}$ Whitman was not entirely insensitive to critiques of Columbus, as "Prayer of Columbus" shows. Nevertheless, Whitman overlooked the explorer's personal and moral failings to stress 
the importance of Columbus's life within the larger course of history. In "Passage to India," for instance, the poet sees "mediæval navigators rise before me, / The world of 1492, with its awaken'd enterprise."Whitman imagines Columbus stepping out from among the crowd of explorers. As the premier embodiment of an age of exploration, Columbus attracted the bitter slander of "calumniators," but Whitman, in "Prayer of Columbus," foregrounds the greater providence of discovery, the seed that sprouts and "fills the earth with use and beauty" ( $L G, 417,418)$.

With the national conversation recurrently parsing Columbus's significance and promoting the Exposition between 1890 and 1893, it is small wonder that folks like William Walsh, George Horton, and Horace Traubel would be thinking of Whitman. Likewise, it is reasonable to think that Whitman would have seen it as felicitous that the country was coming around to his way of thinking in anticipation of the 400th anniversary of the discovery, and thus it would not be surprising for Whitman to return to thoughts of Columbus in this context. Nevertheless, Whitman's collapsed health and then death six months prior to the dedication ceremonies prevented him from capitalizing on the Exposition as he had hoped to do for the Centennial with "Song of the Exposition." In the twenty-three months separating the official announcement of the Columbian Exposition and Whitman's death, he had resisted officially dedicating anything to the fair, but on March 16, 1892, ten days before he was to die, Whitman handed Traubel a manuscript of two sheets upon which were pasted old envelopes and paper scraps: his last poem, "A Thought of Columbus." It is plausible that "A Thought of Columbus" amounts to Whitman's response to requests for a commemorative poem. Envelopes on which portions of the poem were written suggest that some of the poem's lines date to November 1891. Traubel speculated that the poem must have been addressed to the sense of pride in progress associated with the world's fair, and, published in the July 9, 1892, edition of Once $A$ Week, it certainly would have appeared to be implicitly dedicated to the quatercentenary of the discovery if not also to the Columbian Exposition.

Because the poem is not regularly showcased in editions of Whitman's poetry, it bears reprinting here.

\section{A Thought of Columbus.}

The mystery of mysteries, the crude and hurried ceaseless flame,

spontaneous, bearing on itself.

The bubble and the huge, round, concrete orb!

A breath of Deity, as thence the bulging universe unfolding!

The many issuing cycles from their precedent minute!

The eras of the soul incepting in an hour,

Haply the widest, farthest evolutions of the world and man. 
Thousands and thousands of miles hence, and now four centuries back,

A mortal impulse thrilling its brain cell,

Reck'd or unreck'd, the birth can no longer be postpon'd:

A phantom of the moment, mystic, stalking, sudden,

Only a silent thought, yet toppling down of more than walls of brass or stone.

(A flutter at the darkness' edge as if old Time's and Space's secret near revealing.)

A thought! a definite thought works out in shape.

Four hundred years roll on.

The rapid cumulus - trade, navigation, war, peace, democracy, roll on;

The restless armies and the fleets of time following their leader

- the old camps of ages pitch'd in newer, larger areas,

The tangl'd, long-deferr'd eclaircissement of human life and hopes boldly

begins untying,

As here to-day up-grows the Western World.

(An added word yet to my song, far Discoverer, as ne'er before sent back to son of earth-

If still thou hearest, hear me,

Voicing as now-lands, races, arts, bravas to thee,

O'er the long backward path to thee-one vast consensus, north, south, east, west,

Soul plaudits! acclamation! reverent echoes!

One manifold, huge memory to thee! oceans and lands!

The modern world to thee and thought of thee!) ( $L G, 581-582)$

"A Thought of Columbus" voices Whitman's reflections on the significance of Columbus and America in the four hundred years since the explorer sailed, and it reflects the spirit of the Columbian Exposition and the social changes the country was navigating at the time. The deliberate ambiguity of the title indicates that "A Thought of Columbus" is both a paean to the inspiration that impelled Columbus's attempt to sail west to arrive in the East and an occasional poem commemorating the historical outcomes of that act. Like so many of Whitman's poems, it wields associative language and broad, expansive scope to layer history, geography, the cosmos, and Whitman's own brand of mysticism within an accessible conceit. To illustrate his sense of Columbus's historic significance, Whitman envisions the beginning of time, literally the birth of the universe: "A breath of Deity, as thence the bulging universe unfolding." By opening with the birth of the cosmos, Whitman establishes an enlarged scope of time and space to indicate the importance of Columbus and America from the only vantage-point that would make its transcendental significance entirely visible.

Whitman imagines the universe as concentric circles, evoking the earth's cyclical orbit around the sun, and thus in the "Thousands and thousands of miles hence" he reckons time in terms of distance. The mil- 
lennia since the breath of life that set the universe in motion anticipate a momentous revelation: "old Time's and Space's secret near revealing." From this distant cosmic perspective Whitman zooms in on the thought, the moment of inspiration, the flash of genius which motivated Columbus to set out west in search of a trade route with the East. The poem casts that moment of inspiration, that flickering instant, as a supremely important turning-point in the evolution of the universe. With the lines, "A mortal impulse thrilling its brain cell, / Reck'd or unreck'd, the birth can no longer be postponed," Whitman suggests that Columbus's moment of inspiration was fateful and latently carried the overthrow of old orders. "Only a silent thought," he indicates with understatement, "yet toppling down of more than walls of brass or stone."

Having established Columbus's inspiration as a turning-point in universal history, Whitman jumps from Columbus, for whom "A thought! a definite thought works out in shape," to his own historical moment. Calculating the significance he sees in the execution of Columbus's idea, Whitman writes:

Four hundred years roll on.

The rapid cumulus - trade, navigation, war, peace, democracy roll on;

- the old camps of ages pitch'd in newer, larger areas,

The tangl'd, long-deferr'd eclaircissement of human life and hopes boldly

begins untying,

As here, to-day up-grows the Western World.

Whitman attaches this first, inspired thought of Columbus to the transcendence of foregone eras of civilization by all that has developed in the modern world. Out of that one thought has accumulated through the years a new, expansive geography in which old societies and ideas find room to expand and manifest new life in new forms. Alluding to the relocation of the muse in "Song of the Exposition," all that was latent in European culture, all that was waiting to unfold, rolls boldly forth upon relocation to the Americas, and thus the divine secret of history is explained. The thousands and thousands of orbital miles established in the opening of the poem are implied again in the miles Columbus journeyed in carrying the ancient muse of discovery to the Americas. This pattern is evoked again in the four centuries since the discovery as later visionaries have followed Columbus's lead and rounded the globe again and again. With this, Whitman proclaims the blossoming of the Columbian continent, which in "Passage to India" had been figured as a transcendental bridge.

ForWhitman, Columbus's discovery reveals the way the impulses of human ambition, brave individuality, the cycles of history, and the exigencies of physical space cooperate to manifest the transcendental spirit of 
progress he saw embodied in his America. In "Prayer of Columbus" this notion is carried in the supplicant navigator's attribution of his discovery and all its portent to God. In "A Thought of Columbus," the mysteries and secret evolutionary designs of the universe are borne in the germ of Columbus's idea. The lines, "The eras of the soul incepting in an hour, / Haply the widest, farthest evolutions of the world and man," suggest that Columbus's idea marks the turning-point in the universal design toward spiritual transcendence. Columbus is unable to quite reckon the significance of his idea, but he is compelled by a universal need to act on it. Only four hundred years later could such providence begin to be understood; yet for time measured in cosmic terms, four centuries are but an hour. For ages the universe had been preparing for a rapturous transformation, and Whitman sees the rapid accumulation of progress since Columbus as indicating a millenarian immanence.

The cosmic perspective that Whitman takes in the poem is further linked to his longstanding identifications with Columbus. Whitman tacitly establishes a connection between himself and Columbus based on the notion that history, progress, and evolution are together like a road on which the world is traveling toward ever-higher realms of modernity and perfection. Yet, Whitman leavens his road-of-progress metaphor with his idea of the democratic spirit. Whitman saw all humanity, including Columbus and himself, and every person on the street, as treading the same path toward material and spiritual perfection. Through innumerable but very real moments of personal contact, Whitman figuratively reaches back along the road of history to address Columbus directly:

If still thou hearest, hear me,

Voicing as now-lands, races, arts, bravas to thee,

O'er the long backward path to thee-one vast consensus, north, south, east, west,

Soul plaudits! acclamation! reverent echoes!

One manifold, huge memory to thee! oceans and lands!

The address resembles the direct addresses that Whitman so often makes to his readers, particularly those whom he imagines will read his poems generations after him, as in "Poets to Come" and "Crossing Brooklyn Ferry," where he states, "I am with you, you men and women of a generation, or ever so many generations hence" ( $L G, 160)$. Indeed, Whitman represents himself as prophetically linking Columbus and the future. Like Columbus's potent "thought" that generates the America Whitman inhabits, Whitman's own poetry thinks into eventual being the "Modern Man" who will bring democracy to fruition $(L G, 1)$. Registering the social upheaval of his day and compounding the ambiguities of his poem, Whitman delivers the "modern world to thee and thought of 
thee."Whitman himself stands as a bridge. His poem defines the import of Columbus for his contemporaries from across the four corners of the country who were planning their celebration, and he delivers the "bravas" of the Exposition back to Columbus. Both of these he delivers to the future when the "eclaircissement of human life and hopes" will be only more fully understood and enjoyed.

Toughened by his disappointments of the 1870 s and 1880s, particularly that of being overlooked during the 1876 Centennial Exposition, Whitman continued to identify with Columbus as he approached death. Nevertheless, his feelings of dejection seem to have been allayed by hopes that someone would someday (perhaps someday soon) praise him the way he had praised Columbus, as a pioneer of the modern spirit who listened to his own flickering inspiration and bore witness to the exigencies latent in his historical moment. Readers ofWhitman who saw "A Thought of Columbus" in Once AWeek would have detected this. The poem explicitly links "Passage to India" with "Song of the Exposition" and "A Prayer of Columbus," and it ties them directly to the ideologies promulgated by the Columbian Exposition while subtly suggesting to readers that Whitman anticipated much that the world's fair finally exhibited. The poem celebrates America's discovery and products since 1492; it speaks to the westering of civilization and the culmination of progress; it praises the broad continent that supposedly made such political innovations as democracy and technological inventions like the engine important; it speaks to the development of new arts, customs, and social forms appropriate to America; it applauds the freedom from as well as the perfection of European institutions; it advances faith in American transcendence; it implicitly figures the Exposition as a landmark on the road of American progress; and in all this it was perfectly felicitous for the Columbian Exposition.

Were they not so busy with their own agendas, the fair's participants might have more fully registered Whitman's contributions to the Exposition's inherent ideologies. Frederick Jackson Turner would certainly have agreed with and celebrated Whitman's framing of history as dependent upon the Western frontier. Louis Sullivan, who saw himself as an architect for the great democratic averages, certainly appreciated Whitman's suggestion that new ideas and new forms develop within democratic exchange in free spaces. Inventors with products displayed at the fair might have been flattered by Whitman's celebration of the feats of engineers. "See America First" promoters would have agreed with Whitman's favoring of the youthful nation over decrepit European capitals. Buffalo Bill Cody and President Harrison alike would have agreed with Whitman's insistence on the pioneer as the emblematic American. Notwithstanding the qualities of his verse that some found vulgar and perverse, Whitman was so attuned to the national spirit that, while the country marshaled 
its resources and polished up a new image for changing times, his last poem yet distilled the mood of the day. Traubel put it this way: "with his heart in affairs to the very end, this 'thought' of Columbus marks the final lifting of the flame-his last august touch with that divine energy which through a heroic life had imparted to him its highest and rarest potencies of prophecy and song." ${ }^{26}$ And even though Whitman indicated the idea was stupid ( $W W W C, 8: 499$ ), he must have been pleased by the thought that some, even a small group, were lobbying to have him named the official poet of the fair that would represent American and world progress since Columbus. As the Illustrated American aptly put it, Whitman was a child of the new world and a son of American soil, so he would have been the ideal poet to announce the glories of the new dispensation, but America had not yet reached a stage where it could appreciate him, and like Columbus his day of triumph would be postponed.

\section{Kutztown University}

\section{NOTES}

1 The Exposition was initiated by an Act of Congress on April 25, 1890. The legislation called for a celebration of "the four hundredth anniversary of the discovery of America by Christopher Columbus, by holding an international exhibition of arts, industries, manufactures, and the products of the soil, mine, and sea in the city of Chicago." Quoted in "The World's Columbian Exposition at Chicago," The Daily News Almanac and Political Register for 1891, ed. George E. Plumbe (Chicago: Chicago Daily News, 1891), 77. Dedication ceremonies were held on October 21, 1892. The fair officially opened on May 1, 1893, and ran through October 30, 1893.

2 The editorial is quoted in Horace Traubel, With Walt Whitman in Camden (Various publishers, 1906-1996), 8:126. Hereafter, $W W W C$. According to Traubel, Whitman had understood William Walsh to be the author of the Illustrated American piece ("Walt Whitman's Last Poem," Once A Week [July 16, 1892], 3).

3 An excerpt from an address delivered in Denver, Colorado, 1892, is cited in Christopher Columbus and his Monument Columbia, ed. J. M. Dickey (Chicago: Rand McNally, 1892), 372. Hereafter, CCMC.

4 Whitman had indicated there that all of his work was geared toward encouraging the development of "native American individuality," or "the distinctive and ideal type of Western character." See Leaves of Grass, Comprehensive Reader's Edition, ed. Harold W. Blodgett and Sculley Bradley (New York: New York University Press, 1965), 571. Hereafter, $L G$.

5 Beyond Whitman's contemporaries, numerous critics since have illuminated Whitman's identification with Columbus and linked this to the culture, politics, and technological developments of America in the years between the end of the Civil War and the Gilded Age. Stanley K. Coffman Jr. notes that the primary effect of "Passage to India" is to figure motion, which he reads as a transcendental concept and links 
to the depiction of Columbus as both explorer and failure; see "Form and Meaning in Whitman's 'Passage to India," PMLA 70 (1955), 337-349. John Lovell posits that Whitman identified with Columbus because he saw Columbus as a poet "of man's extremest possibilities" in that the explorer "dreamed of distant greatnesses, realized the significance of his dreams, and then went forth to make those dreams come true"; see "Appreciating Whitman: 'Passage to India," Modern Language Quarterly 21 (1960), 138. In "Passage to Less than India: Structure and Meaning in Whitman's 'Passage to India'” Arthur Golden, though critical of the aesthetic quality of the poem, notes that linking Columbus to the Union Pacific Railroad symbolized for Whitman "the divine efforts of heroes, \& their ideas, faithfully lived up to"; quoted in PMLA 88 (October 1973), 1095. In Whitman the Political Poet Betsy Erkkila maintains that "Passage to India" moves "away from the material conditions of America" because Whitman feared that the political instability of the country ultimately undermined his celebrations of democracy and himself as the self-proclaimed poet of democracy. She links this posture to Whitman's pessimistic identification with Columbus in "Prayer of Columbus" (New York: Oxford, 1989), 283-284, 287-288. William Shurr identifies Washington Irving's History of the Life and Voyages of Christopher Columbus as the source of Whitman's understanding of Columbus and goes on to argue that Irving's Columbus, a mystical and apocalyptic figure, inspired Whitman in "Passage to India," "Prayer of Columbus," and "Thought of Columbus" in "The Salvation of America: Walt Whitman's Apocalypticism and Irving's Columbus," Walt Whitman of Mickle Street, ed. Geoffrey M. Sill (Knoxville: University of Tennessee Press, 1994), 142-150. In Walt Whitman's America: A Cultural Biography, David S. Reynolds points out that Whitman features the religious note in "Passage to India." Reynolds contrasts the Columbus as courageous hero of history in that poem to the Columbus as hero of faith in "Prayer of Columbus" (New York: Knopf, 1995), 500, 513. In Walt Whitman: The Song of Himself, Jerome Loving also links "Passage to India" and "Prayer of Columbus," arguing that both poems amount to thinly veiled articulations of Whitman's "complaint about American indifference to Leaves of Grass" (Berkeley: University of California Press, 1999), 334. Although critics have hinted at some connection between these poems and the Columbian Exposition, it has gone unexamined in the scholarship.

6 The poem was originally composed to be read by invitation at the fortieth Annual Exhibition of the American Institute, September 7, 1871, yet Whitman revised it and included it in the second volume of his Centennial edition, Two Rivulets, apparently hoping to attract the attention of the Centennial Exposition's planners and be explicitly asked to commemorate the event. In the 1876 preface, Whitman wrote that "Song of the Exposition" identifies "these great Industrial gatherings, the majestic outgrowths of the Modern Spirit and Practice-and now fix'd upon, the grandest of them, for the Material event around which shall be concentrated and celebrated, (as far as any one event can combine them, ) the associations and practical proofs of the Hundred Years' life of the Republic. The glory of Labor, and the bringing together not only representatives of all the trades and products, but, fraternally, of all the Workmen of all the Nations of the World . . . is, to me, so welcome and inspiring a theme, that I only wish I were a younger and a fresher man, to attempt the enduring Book, of poetic character, that ought to be written about it" (LG, 751). Doubtless Whitman would have felt as strongly about the World's Columbian Exposition. See also Elmar S. Leuth, "Centennial Exposition (Philadelphia)," Walt Whitman: An Encyclopedia, ed. J. R. LeMaster and Donald D. Kummings (New York: Garland, 1998), 111-112.

7 Walt Whitman, The Correspondence, ed. Edwin Haviland Miller (New York: New York University Press, 1961), 2:272. 
8 Robert Muccigrosso, Celebrating the New World: Chicago's Columbian Exposition of 1893 (Chicago: Ivan R Dee, 1993), 3. The Garland remark is quoted in Son of the Middle Border (St. Paul: Borealis Books, 2007), 356.

9 For notes on the firsts associated with the Exposition, see Julie Rose, World's Columbian Exposition: Idea, Experience, Aftermath (http://xroads.virginia.edu/); David Mintner, A Cultural History of the American Novel (Cambridge: Cambridge University Press, 1994), 24; and Eric Larson, Devil in the White City (New York: Vintage, 2003), 247-248. The Pledge of Allegiance was written as a promotional stunt associated with the Exposition for Youth's Companion by Francis Bellamy (Edward Bellamy's cousin). Harrison's proclamation is cited in Christopher Columbus and his Monument Columbia, 159-160.

10 According to Peter Ling, the fair was a precursor of many social and cultural formations of the twentieth century "in which corporate power wielded authority and expertise in the work place while providing the compensations of mass consumption"; see America and the Automobile: Technology, Reform, and Social Change (Manchester: Manchester University Press, 1990), 97. Similarly, Diane Dillon reveals the ways in which the maps of the Exposition conceal the relationships between consumption and production upon which the event was founded within a whole culture of illusions; see "Mapping Enterprise: Cartography and Commodification at the 1893 World's Columbian Exposition," Nineteenth-Century Geographies: The Transformation of Space of the Victorian Age to the American Century, ed. Helena Michie and Ronald R. Thomas (New Brunswick, NJ: Rutgers University Press, 2003), 75-98.

11 Not only was the West touted throughout the fair as a privileged land and the solution to many social ills, but as Robert Rydell has made clear in "A Cultural Frankenstein?: The Columbian World's Exposition of 1893," colonial and nativist attitudes were propped up by the fair's racist exhibitions of subaltern cultures, implying that further colonialist expansion would be another outlet for the expression of American greatness; see Grand Illusions: Chicago's World Fair of 1893 (Chicago: Chicago Historical Society, 1993), 143-175. Whitman must have appreciated Chicago as the choice for the Exposition, as George Horton had guessed. In "Starting from Paumanok" for example, he had written, "Crossing the prairies, dwelling again in Chicago, dwelling in every town, / Observing shows, births, improvements, structures, arts, / Listening to orators and oratresses in public halls, / Of and through the States as during life, each man and woman my neighbor" ( $L G, 25)$.

12 Reid Badger, The Great American Fair: The World's Columbian Exposition and American Culture (Chicago: N. Hall, 1979), 49-52.

13 It must be noted that the fair's organizers deliberately excluded women, blacks, and native peoples. As David Mintner puts it in A Cultural History of the American Novel, "the Court of Honor" was "where 'Greek' temples spoke of the past to the ages, without challenging the Exposition's aggressive nationalism, or its emphatic exclusion of the poor, or its emphatic control of Native Americans, women, and black Americans" (26). According to Robert Rydell, the Exposition was "deeply inscribed with prevailing beliefs about race and gender" and "posited a common culture for some Americans at the expense of others" (169). See also Muccigrosso, 132-153.

14 In his essay, "The Artistic Uses of the Imagination," Sullivan argues that the architect must cultivate imagination over reason to turn craft into true art, and he cites Whitman's "There Was a Child Went Forth" to illustrate this principle; see Louis Sullivan: The Public Papers, ed. Robert Twombly (Chicago: University of Chicago Press, 1988), 66-67. His transportation building illustrated Whitman's linking of transporta- 
tion and spiritual progress, according to Lauren Weingarden in "A Transcendentalist Discourse in the Poetics of Technology: Louis Sullivan's Transportation Building and Walt Whitman's 'Passage to India," Word E Image 3 (April-June, 1987), 212. See also Narciso Menocal, Architecture as Nature: The Transcendentalist Idea of Louis Sullivan (Madison: University of Wisconsin Press, 1981), and Twombly and Menocal, Louis Sullivan: The Poetry of Architecture (New York: Norton, 2000).

15 Frontier and Section (Englewood Cliffs, NJ: Prentice Hall, 1961), 39. See also John Mack Faragher, Rereading Frederick fackson Turner (New York: Henry Holt, 1994); Allan Bogue, Frederick fackson Turner: Strange Roads Going Down (Norman: University of Oklahoma Press, 1998); Mintner, 28; Muccigrosso, 126; Alan Trachtenberg, The Incorporation of America: Culture and Society in the Gilded Age (New York: Hill and Wang, 1982), 11-13, 214.

16 Richard White, "When Frederick Jackson Turner and Buffalo Bill Cody both Played Chicago in 1893," Does the Frontier Experience Make America Exceptional?, ed. Richard W. Etulain (Boston: Bedford/St. Martins, 1999).

17 Regarding the "See America First" movement in the nineteenth century, see Margeurite Shaffer, See America First: Tourism and National Identity 1880-1940 (Washington, DC: Smithsonian, 2001), 7-92.

18 "The Progressive Discovery of America," Century Magazine 43 (January, 1892), 470.

19 "Columbus at Granada," The New York Times (April 17, 1892), 4. See also "The Voyage of Columbus," The Nerw York Times (August 4, 1891), 4.

20 Christopher Columbus, written and composed by the San Francisco Verein (San Francisco: Verein, 1892), 10.

21 "Columbus at the Court of Ferdinand and Isabella," Harper's Weekly (July 5, 1890), 527.

22 For more information on the fleet, La Rabida, and the placement of Columbiana throughout the Exposition grounds, see Julie K. Brown, Contesting Images: Photography and the World's Columbian Exposition (Tuscon: University of Arizona Press, 1994), 59-60, 75, 144n. See also Bolotin and Laing, 71, 105, 109.

23 “The Figure of Columbus," Atlantic Monthly (March, 1892), 411.

24 Charles Kendall Adams, Christopher Columbus: His Life and Work (New York: Dodd and Mead, 1892), 252-256.

25 Harry Hakes, The Discovery of America by Christopher Columbus (Wilkes-Barre, PA: Robert Baur and Son, 1892), 11, 132.

"Walt Whitman's Last Poem," 3. 